\title{
RUSSIAN LANGUAGE SPEAKERS: SOME OBSERVATIONS ON THEIR COMMUNICATIVE BEHAVIOR
}

\author{
ANDREI SHATILOV \\ University of Saint Petersburg \\ ashatilov2@gmail.com \\ ORCID: 0000-0003-3865-0802
}

ABSTRACT

The paper presents the description of specific communicative practice among the Russian language speakers. This research is based on linguistic and cultural data collected in everyday speech and behavior, as well as in the Russian philosophical and literary tradition. The following elements of verbal communication were analyzed: syntactic structures, lexical units, and phonetics. Sociocultural phenomena, such as role-switching, use of background knowledge, and talk domination were observed too. Generally, the method applied here could be defined as content analysis. The findings of the present study suggest that the typical features of the communicative style in the Russian culture are straightforwardness, familiarity, gender and race intolerance, aggressiveness, rude language, irony, and emotionality.

KEYWORDS: Communicative Style, the Russian Language, Content Analysis, Verbal Communication

\section{INTRODUCTION}

In recent years, there has been an increasing interest in so-called communicative behavior. Researchers have studied communication from different angles, including Sociocultural aspects (Knapp, Daly 2010; Overall, Sibley, Travaglia 2010; West, Turner 2000). The focus of studies has been on verbal behavior, nonverbal behavior, or communication behavior. None of these categories represents a fixed set of behaviors; therefore it is the researchers' responsibility to identify the specific behaviors that they wish to study.

Global intercultural interaction requires mutual comprehension in the communication field. Numerous studies have attempted to explain how people behave in communicative settings, what the rules are, and what one should know to understand others (Hymes 1974; Leech 1983; Grice 1991; Hall 1990). The objective of the present study is the description of some essential characteristics in Russian communicative behavior. This research is based on linguistic and cultural data, collected in everyday speech and behavior, as well as in the Russian philosophical and literary tradition.

Each culture has a specific set of communication rules and characteristics. As Bergelson states: "It is hard to say what and to what extent has to be acquired so that a person may function constructively in a given culture. Learning certain specific traditions may seem useless or better to say - of ethnographic, not 
practical value" (Bergelson 2003). On the other hand, it might be useful to understand some cultural features, such as forms of greetings, compliments, complains and others. A basic cultural value (such as emotionality or directness in the Russian language) is the knowledge to be learned. That knowledge can be structured and organized in a compact way (ibid. p.98).

Ratmayr (1992) and Wierzbicka (1998) have demonstrated oppositions generally valid for interpersonal communication between Americans (As) and Russians (Rs) (to mention only a few): for Rs directness with familiars is associated with sincerity, while for As directness with familiars is associated with imposition on their freedom; Rs value positive politeness more than negative while As pay more attention to negative politeness; for Rs apologizing is more of expressing compassion while for As apologizing means taking responsibility for the offence (Bergelson ibid. 8).

In Great Britain, for instance, one of the typical features of conversation style is uncertainty (Fox 2005). The Russian style, generally, tends to openness and sincerity; participants of intercultural communication would be aware of such rules and norms, and how they are realized in the Russian language in different areas of functioning. The present study carried out analysis of some unwritten conventions in interpersonal interaction in the modern Russian language.

\section{MethodS}

As this research focuses on description of communicative rules, the data were collected from different sources, in particular, from recorded talk, published examples of spoken language, fragments of literature texts, containing elements of oral discourse. TV talk-shows are also included into the analysis. Some Internet based sources are of great help too, namely, the ORD Speech Corpus of Russian Language. The method of participant observation is also used. The following elements of verbal communication were analysed: syntactic structures, lexical units, and phonetics. Sociocultural phenomena, such as role-switching, background knowledge use, and talk domination were observed too. Generally, the applied method could be defined as content analysis.

\section{RESULTS}

The area of communication is very wide. Researchers who are working within it apply different approaches to examine communicative behavior. West \& Turner (2000) state that communicative behavior includes the following elements: Vocalics, Proxemix, Artifacts, Movement and Chronemics . The first element refers to how loud/fast the speaker talks (volume/rate), their tone and pitch of voice. The second describes the speaker's use of space when they try to deliver a message. The next one refers to the speaker's use of objects to relate a message. The last but one refers to the speakers' use of body language, facial 
expression, posture and eye contact in speech. The fifth defines the speaker's use of time. Linguistic approaches to determining intercultural communicative competence have been applied by Knapp (1998) and Knapp-Pothoff (1997). In their approach, this competence is understood as the ability to achieve an equally successful understanding with members of other cultures and communication networks as with one's own. There are at least three components of this ability:

1. a specific knowledge of patterns of communicative action and interpretation in one's own as well as foreign language and culture

2. general knowledge about the relation between culture and communication (including the dependence of speaking and acting on culture-specific cognitive schemata)

3. a stock of interaction-stabilizing strategies (e.g. for establishing common ground on the relationship level (Knapp 1998)

One perspective on today's understanding can be found in Knapp \& Daly's preface to their handbooks of Interpersonal Communication. They explain that today "interpersonal communication scholarship focuses on more than simply behavior. People have different attitudes and personal goals that affect how they communicate. They sometimes come from different cultures, they vary in personality dispositions, and they have different life-histories" (Knapp, Daly 2010: xxiii).

Communicative behavior as a concept was introduced into Russian scientific discourse by Sternin (Sternin 1989). Sternin and Prohorov (2006) present it as behavior (verbal and non-verbal one accompanying it) of a person or groups in the communication process, which is regulated by communication norms and traditions of the given society. Obviously, the concept of "communicative behavior" is wider than the concept of "verbal behavior" (Kortunov 2013).

Generally, linguists researching cross-cultural communication and related issues from the perspective of cultural anthropology are in agreement about the significance of basic cultural values that reflect a culture's world view. Adopting this view, Hall introduced the concept of a high-context and a low-context culture. In a high-context culture the message contains little explicit information because most of the information is already in the person (Hall p.6). A low-context culture, on the other hand, requires much more background information when a person is engaging in an interaction because the information lies within the explicit code. Our suggestion, supported by some researchers, is that the Russian culture is more high-context because a substantial part of required information is not explicit (Stefanenko 1999, Paduchewa 1995, Wierzbicka 1992). Sharing the same cultural and historic background, the speakers might use a hint or allusion instead of giving full description. Basing on comparative studies of French and Russian business culture, Sheypack (2012) claims that both cultures are highcontext, thus the interaction should be focused upon personal relationships. The 
communicants are supposed to hold to all formalities required by etiquette and social status. However, when colleagues become friends this frame may be reconsidered. As Prokhorov and Sternin state, the most relevant features for Russian mentality are unity or solidarity, emotionality, impulsiveness, law neglect (Prokhorov \& Sternin 2006). Taking into account the results of studies, some more characteristics could be named. They might be distributed into two main groups - related to culture and related to communication.

The first group includes:

-directness (the evaluation of a person or an opinion that might be expressed directly and quite often in a rather straightforward form) -familiarity (the participants tend to familiarize as soon as possible irrespective of their work or social status) -gender, ethnical or racial intolerance -aggressiveness (the participants generate conflicts using provocative strategies)

-talk domination (the speakers are inclined to underestimate the right of others in switching turns, being more talk active than needed) -frequent usage of mimics and gestures (mostly, mimics reveal positive feelings and emotions, while negative attitude tends to be hidden; the amplitude of gestures is wide, they occupy more space and may penetrate into their communication partner's personal area. Petrova (1998) notes that Russian gestures could be used separately without verbalization). The smile in Russian culture is a signal of personal favor or sympathy which is unlike, for instance, an American smile, which is simply a sign of politeness. A stranger would hardly be greeted with a smile. Serious situations require serious language, so there is no place for smiling. Meanwhile, smiling is an appropriate way to release tension in formal situations.

-short communicative distance (the speakers pose at the distance of hand reach, which is allowed - hand, shoulder or elbow might be touched; physical contacts are not considered as harassment) -communicative control (the participants evaluate and control the correctness of the language; breaking the rules leads to a fast and sharp reaction, and the "violator" is strictly advised to learn the language first and then take part in the discussion; dressing style, hair style, way of smiling or speaking, child treatment, i.e. almost any aspect of personal behavior might be the object of criticism).

-a large scale of discussed information (the talk turns quickly from one topic to another involving a huge amount of data or rumors) -the priority of heart-to-heart conversation over small-talk (the appropriate topics for conversation should be serious and important, e.g. politics, 
economics, education, arts, religion, etc. Food, restaurants, personal relations, sex, hobbies, sports are considered insignificant).

-oncoming questions (when asked, the speaker reacts with an oncoming question instead of the answer)

-interruption (the speaker could be interrupted at any moment of conversation. Even more, the partners are aware of this and are ready to stop speaking abruptly)

-low level at listening. Following Hall's divisions into monochromic and polychromic cultures (Hall, Hall 1990), we can define the Russian culture as mostly polychromic with some monochromic elements. In monochromic cultures, the person is supposed to complete one action in one period of time. When accomplished, the second action could be performed. In polychromic cultures, the person is allowed to perform a number of activities simultaneously. Russian communicative behavior permits speaking over the phone, signing documents, talking with a client and listening to someone at one moment. Unsurprisingly, it leads to low concentration upon single action. As a result, the Russians are perceived as inattentive and uneducated partners.

The second group contains communicatively related features, namely -reactivity (reaction to a remark follows immediately, even before the previous phrase is finished)

-rude language (a witty remark is considered more appropriate than refined and subtle language)

-humor and irony (humoristic and ironical remarks are a substantial part of communication; examples of schprachspiel (Wittgenstein) are numerous: $e$ mail converts into Emelja, an old Russian male name, so it forms the verb emelit' - to send an e-mail; a keyboard is called klaviatura or klava which sounds like the Russian female name Klava; sms is pronounced as esemeska and produces the verb esemesit', etc. Speakers are surprisingly creative generating thousands of new humoristic and ironical forms -quotations (educated speakers widely use all sorts of well-known proverbs, quotations, slogans, anecdotes, phrases of eminent writers or politicians, Biblicisms, idioms. This phenomenon is undoubtedly quite common among native speakers).

To illustrate the listed characteristics, we provide some examples of recorded conversation.

Episode 1. Fragment of the TV-show Casual relationship recorded January 18, 2011. A randomly chosen TV-viewer could ask any questions to the group of comedians in the Moscow studio which they have to answer. Here one can notice some features of communicative behavior mentioned above. 
Ivan (TV-viewer) - 1I have a question - is it possible for beginning oligarch to rent a room at Rubljevka? (Rubljevka - very prestigious and expensive Moscow suburb) Comedian $1-{ }^{2}$ You know, Ivan, I have an oncoming question $-{ }^{2}$ Why is there a flag of the Russian Federation tossed behind you? ${ }^{3}$ Do you cover everything up with the flag, kind of? ${ }^{4}$ What's under it?

Comedian 2 - ${ }^{5}$ Ivan is a beginning oligarch, here he keeps a stolen bucket of oil... Comedian 1 - ${ }^{6}$ Speaking about beginning oligarchs - they all live in a dormitory, more over they do not pay the rent under one condition: later they have to return the payment.

Comedian 3 - 7 That is why...

Comedian $1-{ }^{8}$ Yes

Comedian 3 - ${ }^{9}$ there are golden toilet pans. ${ }^{10}$ It is a unique dormitory...

Comedian $2-{ }^{11}$ And if you aren't able to return the payment, you will be installing golden pans.

Original version:

Иван - у меня вопрос - сдают ли жители Рублевки комнаты
начинающим олигархам?
Комик 1 -Вы знаете, Иван, скажите, у меня встречный вопрос - Почему у вас сзади лежит брошенное знамя Российской Федерации? Типа, вы все прикрываете знаменем, да? Что там такое у вас под знаменем?

Комик 2 - Иван начинающий олигарх, там у него ведро нефти, которое он украл, а-а

Комик 1-Насчет начинающих олигархов - они все живут в общежитии, более того они вообще ничего не платят, потому что их берут в общежитие с одним условием - потом отдадите.

Комик 3 - Поэтому...

Комик 1 - Да

Комик 3 - в нем золотые унитазы. Это единственное общежитие...

Комик 2 - А если не отдашь потом, то будешь там вот монтировать золотые унитазы.

The episode starts with the question that contains two important concepts for the Russian culture - Rubljevka and oligarch. As explained previously, Rubljevka is a status-marked place that confirms one's success or richness. Politicians, businessmen, high-ranked functionaries, move-stars, pop-stars, and successful writers must have a house over here. The second concept - oligarch covers a group of extremely rich people, who head large state or private companies such as Rosneft', Gasprom, Russian Railways. Therefore the question is not correct because the Rublievka's people evidently do not lease rooms. Ivan who asked the question knows perfectly well, that too, so his purpose is to provoke the comedians to generate an ingenious answer.

The phrases № 2-4 illustrate early mentioned feature, i.e. oncoming questions. The comedian 1 instead of answering the question puts another one to his partner. The question draws the audience's attention to the flag which covers up something. To a native speaker there is a clear allusion on unpleasant 
manipulations done by oligarchies under governmental cover. The comedian 2 says that Ivan stole a bucket of oil just like oligarchies steal natural resources of the country. In phrase 6 the first comedian explains that the oligarchs live in a dormitory and do not pay the rent. Apparently, it is a joke, however he is partially right, because some of the oligarchies started their business living in student's dormitories. The comedian 3 remark about the golden pans is presenting them as a symbol of prosperity and a dream for beginning businessmen. The last comment (№ 11) illustrates widely shared stereotype: if you are not rich enough to live in a house with golden pans, you will be doing low-paid work.

Generally, the whole conversation represents a set of comments about the topic, given by the participants with no real answer to the asked question. All comedians try to look witty and sharp-minded; the reactions are fast, they interrupt each other constantly, and talk simultaneously.

Episode 2 represents a part of a dialogue recorded in photo salon at June 21, 2009 in Saint-Petersburg. A couple of clients come in to get a photo for the passport made.

\section{Episode 2.}

Photographer - ${ }^{1}$ So, let's get back to work. ${ }^{2}$ Where are my keys? ${ }^{3}$ I am here, over there.

Client $1-{ }^{4}$ You and ... the passport?

Ph. - 5 Yes

$\mathrm{Cl} .1-{ }^{6} \mathrm{Oh}$

Ph. $-{ }^{7}$ Analog?

Cl.1 $-{ }^{8}$ Analog

Ph. $-{ }^{9}$ And why do we need the analog?

Cl. $1-{ }^{10}$ Well...

Cl. 2 - ${ }^{11}$ Well, a foreign passport

Ph. - ${ }^{12}$ I see, just now they make ... that is it ... and you were told exactly analog, right?

Cl.1 $-{ }^{13}$ Generally, yes.

Cl. $2-{ }^{14}$ No, yes, I went there, asked them, it is possible to have both.

Ph. -15 Yes.

Cl.1/ Cl. $2-16$ Well / I do not want it

Ph. $-{ }^{17} \mathrm{Ok}-$ Ok. ${ }^{18^{\prime \prime}}$ If the country orders, I will not fear. Comrade Time, comrade Time". ${ }^{19} \mathrm{Be}$ the order, we will not be afraid. ${ }^{20}$ So, where is my film?

Original version:

Фотограф - Ну, пойдем трудиться. Где мои ключики? Я тута, я здеся.

Клиент 1 - Вы... и паспорт?

Ф. - Да.

Кл.1 - Ой

Ф. -Аналоговый?

К. 1 - Аналоговый 
Ф.- А зачем нам аналоговый паспорт?

К.1 - Ну...

К. 2 - Ну, загранпаспорт

Ф. - Я понимаю, сейчас просто ... сейчас берут то и всё ... а вам ... конкретно сказали аналоговые, да?

К. 1 - В общем, да.

К. 2 - Нет, да, я же ходил, узнавал, можно такой и такой .

Ф. - Да.

К. 1/ К.2 - Ну / Мне не хочется.

Ф. - Хорошо-хорошо. «Если родина прикажет , я не струшу. Товарищ время, товарищ время». Будет приказ, не с... струсим. Так, где у меня плёночка?

Two things are worth to note. The first one (lines 8-10) shows again an example of an oncoming question, when the photograph asks the clients whether they really need the analog passport instead of doing their request. He uses the form we in his question (And why do we need the analog?) including himself in the group, probably, to familiarize with the clients. Secondly, lines 18-19 are an example of background cultural information shared by native speakers. The photographer quotes the Soviet song written in 1973 and performed in the TVserial "As the steel was tempered" (Kak zakalyalas' stal') that tells about the Revolution in Russia in 1917. The song reflects the demand of revolutionary time, when people had to do what was needed independently of their wishes and possibilities. In actual context, it means that any client's request should be accomplished. The photographer, evidently, is not a young person, so he most likely might have seen that film and remembers the song. In addition, he uses the low colloquial version tuta and zdes'a instead of regular forms tut and zdes' (both mean here, over here). Surely, he knows how to pronounce the words correctly but he used the distorted forms on purpose - to add elements of humor to the conversation.

\section{DISCUSSION}

This study indicates that in the Russian communicative behavior traditions are more valuable then norms whereas in Western communication style it is vice versa. The cross cultural communication demonstrates the unlikeness of each communicative style and demands to consider the differences. While speaking with Russian people, a foreign person should not be surprised when asked directly about his or her marital status, income, car, or health. For Western people these types of questions are inappropriate because they interfere with their privacy. The last category, apparently, determines the w33hole structure of communicative behavior, at least with regard to Anglo-American tradition. In Russian culture an individual is less significant than a community therefore group values overcome individuals. 
The findings of the present study suggest that the typical features of the communicative style in the Russian culture are straightforwardness, familiarity, gender and race intolerance, aggressiveness, rude language, irony, and emotionality. The results presented here may facilitate improvements in cross cultural communication.

\section{BIBLIOGRAFY}

BERGELSON, M. (2003), Russian cultural values and workplace communication styles, in: Communication Studies 2003: Modern Anthology, Volgograd, Peremena, 97-112.

FOX, K. (2005), Watching the English. The Hidden Rules of English Behavior, London, Hodder \& Stoughton

HALL, E. T.; HALL, M. R. (1990), Part 1: Key concepts: underlying structures of culture, in HALL, E. T.; HALL, M. R. (1990), Understanding cultural differences, Intercultural Press, 3-31.

KNAPP, K. (1998), Intercultural communication in EESE, EESE strategy, 4. Erfurt, Universitat Erfurt. http://webdoc.sub.gwdg.de/edoc/ia/eese/strategy/knapp/4_st.html

KNAPP, M. L.; DALY, J. A. (2010), Editors' introduction: Interpersonal communication, in KNAPP, M. L.; DALY, J. A. (2010), Interpersonal communication, volume 1: Introduction, history and communicator characteristics, Los Angeles, Sage, xxi-xxxiii.

KNAPP-POTHOFF, A. (1997), Interkulturelle Kommunikationsfähigkeit als Lernziel, in: KNAPP-POTHOFF, A.; LIEDKE, M. (1997), Aspekte interkultureller Kommunikationsfähigkeit, München, Judicium, 181-205.

KORTUNOV, V. (2013), Prolegomena to the methodology of verification of irrational systems, World Applied Sciences Journal, 22(8), 1180-1194.

LEONTOVICH, O.A. (2003), Russia and the USA. Introduction to Intercultural communication, Volgograd, Peremena.

ORD Speech Corpus of Russian Language, Available at http://model.org.spbu.ru (assessed January 4, 2016)

OVERALL N.S.; SIBLEY S.G.; TRAVAGLIA, K. (2010), Loyal but ignored: The benefits and costs of constructive communication behavior, Personal Relationships, $17,127-148$.

PADUCHEVA, E.V. (1985), Utterance and its correlation with reality, Moscow, Nauka.

PETROVA, E.A. (1998), Gestures in educational process, Moscow, The Pedagogical Society of Russia.

RATMAYER, R. (1998), Prostite, esli êto ne tak, ili k voprosu o formach izvinenija v russkoj ustnoj recii, in Liki Jazyka, Moskva, Nasledie.

SHEYPAK, S.E. (2012), French and Russian business culture: cross cultural dialogue, Actual social studies, 2.

STEFANENKO T.G. (1999), Ethnopsychology, Moscow, Institute of Phsychology RAN.

STERNIN, I.A. (1989), About the concept Communicative behavior, Kommunikativfunktionale Sprachbetrachtung, Halle, 279-282. 
STERNIN, I.A., PROKHOROV, J.E. (2006), Russians: communicative behavior, Moscow, Flinta- Nauka.

WEST, R.; TURNER, L. H. (2000), Introducing communication theory: Analysis and application, Mountain View, CA, Mayfield.

WIERZBICKA, A. (1992), Semantics, Culture and Cognition: Universal human concepts in culture-specific configurations, Oxford \& New York, Oxford University Press. 